\title{
FAKTOR-FAKTOR PENYEBAB NIKAH SIRI DI SULAWESI BARAT
}

\author{
Juraeri Tahir \\ A. Qadir Gassing HT \\ Achmad Abubakar \\ Kasjim Salenda \\ Kantor Kementerian Agama Kabupaten Mamuju \\ Juraeritahir@gmail.com, achmad.abubakar@uin-alauddin.ac.id
}

\begin{abstract}
Abstrak: Tulisan ini akan mengungkapkan tentang faktor-faktor terjadinya nikah siri di Sulawesi Barat. Penelitian ini adalah penelitian deskriptif kualitatif untuk menggambarkan kondisi faktual dari kecenderungan masyarakat Sulawesi Barat dalam melakukan nikah siri. Penelitian ini dilakukan di Sulawesi Barat yang meliputi tiga Kabupaten kota, yaitu Mamuju, Mejene dan Polman. Pendekatan yang digunakan adalah pendekatan yuridis normative, fenomenologis, filosofis, dan sosiologis. Penelitian ini menggunakan data primer yang diambil dari sumber-sumber utama, yaitu para responden yang terdiri dari pelaku nikah siri, pejabat desa, pejabat KUA, dan pejabat Pengadilan yang berkompeten menjawab penelitian tentang nikah siri. Data sekunder diambil dari sumber-sumber lain, yaitu tulisan-tulisan yang terkait dengan formulasi hukum nikah siri dan buku-buku tentang sosiologi hukum dan filsafat hukum Islam sebagai alat pembedah terhadap penelitian ini. Data dikumpulkan dengan metode wawancara dan observasi dengan instrumen pedoman wawancara. Data diolah dan dianalisis dengan reduksi data, penyajian data, penarikan kesimpulan atau verifikasi. Keabsahan data diuji dengan triangulasi.

Hasil penelitian menunjukkan baha faktor-faktor terjadinya nikah siri di Sulawesi Barat di kalangan laki-laki adalah karena menganggap buku nikah tidak penting, kurangnya sosialisasi pentingnya pernikahan yang tercatat, memang ingin menikah 2 kali/poligami, suami melakukan pernikahan tanpa izin istrinya, kurangnya perhatian dan pelayanan seks dan menghindari perzinahan. Sementara di kalangan perempuan, alasan mereka melakukan nikah siri antara lain adalah karena kebutuhan batin, tidak mendapatkan kepuasan dari suaminya, mencari laki-laki yang mapan dalam bidang ekonomi, sehingga dapat membiayai hidupnya, adanya jumlah perepuan yang terlalu banyak dibanding laki-laki.
\end{abstract}

\section{Keywords: Nikah Sirri, Sulawesi Barat, Poligami}

\section{PENDAHULUAN}

Pernikahan bagi umat Islam merupakan ikatan lahir batin antara seorang lakilaki dan seorang perempuan sebagai suami istri berdasarkan akad nikah yang diatur dalam undang-undang dengan tujuan membentuk keluarga sakinah atau rumah tangga yang bahagia sesuai hukum Islam. Atas dasar ini, maka dalam pernikahan itu terdapat sebuah kesepakatan bahwa pernikahan itu dilihat sebagai sebuah akad, kontrak, atau perikatan. Pengertian pernikahan sebagai sebuah akad sesuai dengan pengertian yang dimaksudkan oleh undang-undang. Akad nikah dalam sebuah pernikahan memiliki 
kedudukan yang sentral. Begitu pentingnya akad nikah, sehingga ditempatkan sebagai salah satu rukun nikah yang disepakati. Kendati demikian tidak ada syarat bahwa akad nikah itu harus dituliskan atau diaktekan. ${ }^{1}$

Namun sejalan dengan perkembangan zaman di mana dinamika masyarakat terus berkembang dan berubah, maka sangat banyak perubahan-perubahan yang terjadi. Pergeseran kultur lisan kepada kultur tulis sebagai ciri masyarakat modern, menuntut dijadikannya akta, surat sebagai bukti autentik. Saksi hidup tidak lagi bisa diandalkan, tidak saja karena bisa hilang dengan sebab kematian, manusia dapat juga mengalami kelupaan dan kesilapan. Atas dasar ini diperlukan sebuah bukti yang abadi itulah yang disebut dengan akta, yang bisa dikatakan merupakan kebutuhan yang sangat mendesak atau sangat penting.

Namun di sisi lain, terdapat pernikahan dalam masyarakat yang diakui dan diterima oleh syariat, yakni pernikahan yang disebut dengan nikah siri. Nikah siri sebagaimana yang dipahami dalam hukum pernikahan Indonesia sebagai pernikahan di bawah tangan atau pernikahan yang tidak ternyatat merupakan bagian dari tradisi masyarakat Indonesia termasuk masyarakat di Sulawesi Barat.

Sebagai sebuah tradisi masyarakat, maka pernikahan siri ini tentu dipengaruhi oleh berbagai faktor sosial budaya masyarakat bahkan fenomena pernikahan di bawah tangan atau nikah siri bagi umat Islam di Indonesia masih terbilang banyak. Bukan saja dilakukan oleh kalangan masyarakat bawah, tapi juga oleh lapisan masyarakat menengah ke atas. Hal ini disebabkan oleh karena masih banyak di antara masyarakat kita yang belum menyadari dan memahami sepenuhnya betapa pentingnya pencatatan pernikahan.

Kalaupun dalam kenyataannya pernikahan itu dicatatkan di KUA sebagian dari mereka boleh jadi hanya sekedar ikut-ikutan belaka. Atau mungkin mereka menganggapnya sebagai tradisi yang lazim dilakukan oleh masyarakat setempat. Boleh jadi pencatatan pernikahan itu hanya dipandang sekedar soal administrasi, belum dibarengi dengan kesadaran sepenuhnya akan segi-segi manfaat dari pencatatan pernikahan tersebut. Padahal pencatatan pernikahan yang merupakan perintah undangundang itu sesungguhnya mempunyai tujuan penting, yakni proses dokumentasi atas perbuatan hukum pernikahan itu sendiri sehingga kemudian akan memberikan perlindungan hukum bagi suami isteri yang bersangkutan beserta anak turunnya di kemudian hari, sehingga dimulai dari terbentuknya keluarga sebagai unit masyarakat terkecil yang tertib hukum akan tercipta kehidupan masyarakat bangsa yang madani.

Permasalahannya ialah, mengapa begitu rendah kesadaran dan pemahaman hukum sebagian masyarakat Indonesia dalam hal pencatatan pernikahan dan bagaimana upaya pemerintah untuk meningkatkan kesadaran hukum bagi mereka. Semua itu tentu merupakan tanggung jawab bersama antara pemerintah yang memposisikan dirinya sebagai negara hukum dan keseluruhan bangsa Indonesia sebagai masyarakat hukum. Kalau suatu kelompok masyarakat dalam suatu wilayah hukum di Indonesia belum mempunyai kesadaran dan pemahaman hukum yang tinggi, hal ini tentu bukan semata-mata kesalahan masyarakat itu sendiri melainkan juga disebabkan kurang maksimalnya peran dan upaya lembaga pemerintahan yang terkait dalam memberikan edukasi terhadap masyarakat tentang betapa pentingnya mencatatkan pernikahan mereka.

\footnotetext{
${ }^{1}$ Khairuddin Nasution, Status Wanita di Asia Tenggara: Studi Terhadap Perundang-undangan Pernikahan Muslim Kontemporer di Indonesia dan Malaysia (Jakarta-Leiden: INIS, 2002), h. 139.
} 
Rendahnya kesadaran hukum masyarakat akan pentingnya mencatatkan pernikahan, berdasarkan pengamatan penulis, dapat dilihat di beberapa kecamatan dalam wilayah kabupaten di Mamuju, Majene dan Polman dan ternyata ditemukan fakta yang cukup mencengangkan, yaitu ternyata masih terdapat begitu banyak masyarakat yang pernikahannya tidak dicatat oleh KUA setempat. Hal ini dapat diketahui dengan banyaknya masyarakat yang mengajukan permohonan pengesahan pernikahan (isbat nikah) ke Pengadilan Agama setempat untuk mendapatkan pengesahan pernikahan mereka secara hukum negara dalam sebuah program sidang keliling.

Salah satu fakta yang menarik, bahwa mereka tidak mencatatkan pernikahannya antara lain adalah karena alasan mahalnya biaya pencatatan pernikahan. Fenomena mahalnya biaya pencatatan pernikahan ini harus jadi catatan penting bagi para pengambil keputusan untuk menekan biaya pencatatan pernikahan seminimal mungkin agar kelompok masyarakat bawah tidak terhalang kepentingannya untuk memperoleh akta nikah. Faktor lain adalah bahwa sebagian masyarakat ada yang bersikap masa bodoh terhadap ketentuan peraturan yang menyangkut pernikahan. Sikap apatis semacam ini merupakan hambatan besar bagi terlaksananya pemberlakuan penetapan hukum.

Faktor berikutnya adalah bahwa ketentuan pasal 2 UU No.1 / 1974 merupakan azas pokok dari sahnya pernikahan. Ketentuan ayat (1) dan (2) dalam pasal tersebut harus dipahami sebagai syarat kumulatif, bukan syarat alternatif sahnya suatu pernikahan. Dari norma hukum tersebut sebenarnya sudah cukup menjadi dasar bagi umat Islam terhadap wajibnya mencatatkan pernikahan mereka. Akan tetapi ketentuan tersebut mengandung kelemahan karena pasal tersebut multi tafsir dan juga tidak disertai sanksi bagi mereka yang melanggarnya.

Faktor yang tak kalah pentingnya adalah ketatnya izin poligami disebabkan karena dalam UU No.1/1974 menganut azas monogami. Sekalipun demikian, undangundang tersebut masih memberikan kelonggaran bagi mereka untuk melakukan poligami namun dengan persyaratan yang sangat ketat. Seseorang yang hendak melakukan poligami harus memenuhi sekurang-kurangnya salah satu syarat alternatif yang ditentukan secara limitatif dalam undang-undang, yaitu isteri tidak dapat menjalankan kewajibannya sebagai isteri, isteri mendapat cacat badan atau penyakit yang tidak dapat disembuhkan, isteri tidak dapat melahirkan keturunan (ps.4 ayat (2) UU 1/1974).

Sulit dan lamanya proses serta hambatan berupa birokrasi dalam pemberian izin memang bertujuan untuk memperkuat secara selektif akan perkenan poligami bagi PNS serta menghindari kesewenang-wenangan dalam hal kawin lebih dari satu, sehingga PNS diharapkan jadi contoh dan teladan yang baik sesuai dengan fungsinya sebagai abdi negara dan abdi masyarakat. Akibat larangan berpoligami atau sulitnya memperoleh izin poligami justru membuka pintu pelacuran, pergundikan, hidup bersama dan poligami illegal. ${ }^{2}$

Sementara itu, pernikahan yang dilakukan di luar ketentuan hukum tidak akan mendapat pengakuan dan tidak dilindungi oleh hukum. Tindakan tidak mencatatkan pernikahan, walaupun pern ikahan telah dilakukan sesuai dengan ajaran agama Islam, dianggap telah melakukan penyelundupan hukum, alias tidak taat hukum. Indonesia

${ }^{2}$ R. Soetojo Prawirohamidjojo, Pluralisme Dalam Perundang-undangan Pernikahan di Indonesia (Surabaya: Airlangga University Press, 1994), h. 53. 
adalah negara hukum, dan segenap bangsa Indonesia harus tunduk kepada hokum yang berlaku di Indonesia. Undang-Undang Nomor 1 Tahun 1974 adalah hukum negara Indonesia yang mengatur tentang pernikahan. Maka sejak diundangkannya undangundang tersebut, bangsa Indonesia terikat oleh undang-undang itu karena sifatnya yang memaksa, oleh karenanya harus ditaati dan dijalankan. ${ }^{3}$

Kejelasan status pernikahan suami istri melalui bukti autentik tentang pernikahan mereka, menjadi landasan bagi kejelasan status hukum seorang anak. Misalnya untuk pengurusan akta kelahiran si anak, landasannya adalah surat nikah, jika suami istri tersebut tidak pernah mencatatkan pernikahannya, maka ketika lahir anak dan memerlukan akta kelahiran, sehingga kantor kependudukan tidak akan mengeluarkan akta kelahiran dimaksud. ${ }^{4}$

Dalam kehidupan bermasyarakat dan bernegara, kejelasan status seseorang sebagai suami atau sebagai istri merupakan suatu keharusan. Kepastian status itu dapat dilihat dari bukti pernikahan mereka, dalam bentuk akta pernikahan. Sebaliknya, suami istri yang tidak mempunyai akta pernikahan sebagai akibat pernikahannya tidak dicatatkan, tidak memberikan kepastian hukum terhadap pernikahan mereka, seehingga, walaupun hidup dalam rumah tangga sebagai pasangan suami istri, namun keduanya sulit mendapatkan pelayanan hukum dalam kehidupan bernegara di Indonesia.

Pernikahan yang tidak dicatat atau pernikahan di bawah tangan dapat berakibat mengganggu kemaslahatan agama, yang ajaran agama cenderung dipraktekkan secara kacau. Kekacauan tersebut dapat digambarkan bahwa apabila suatu akad nikah tidak dicatat secara resmi di hadapan pejabat yang berwenang, yakni Pegawai Pencatat Nikah (PPN), maka akad nikah seperti ini cenderung tidak dapat dikontrol, yang pada akhirnya dapat membuka peluang pada suami untuk melakukan akad nikah kembali dengan perempuan yang lain tanpa terlebih dahulu mendapatkan persetujuan secara resmi dari istri pertama melalui proses persidangan. Perilaku seperti ini cenderung akan terulang kembali sampai akhirnya suami pun berpotensi memiliki istri melebihi dari ketentuan agama. Dengan demikian, perilaku seperti ini akan menjadi gangguan terhadap kemaslahatan agama.

Pernikahan yang tidak tercatat atau pernikahan siri dapat mempengaruhi kemaslahatan psikologis istri dan anak, mereka pun merasa tidak nyaman dan tidak tenang. Terlebih ketika anak memasuki usia sekolah dan ketika didaftarkan. Setiap lembaga pendidikan selalu mensyaratkan kepada pendaftar (orang tua anak), salah satunya adalah akte kelahiran anak. Syarat untuk membuat akte kelahiran anak adalah buku nikah, dan orang yang memiliki buku nikah adalah orang yang ketika melangsungkan akad nikah mencatatkan pernikahannya.

\section{KAJAN TEORETIK}

\section{Pengertian Nikah Siri}

Dalam Kamus Besar Bahasa Indonesia, kata "nikah" diartikan sebagai (1) perjanjian antara laki-laki dan perempuan untuk bersuami istri (dengan resmi), (2)

\footnotetext{
${ }^{3}$ M. Anshary MK, Hukum Perkawinan di Indonesia; Masalah-Masalah Krusial (Cet. I; Yogyakarta: Pustaka Pelajar, 2010), h. 45.

${ }^{4}$ M. Anshary, Hukum Perkawinan di Indonesia...., h. 47.
} 
pernikahan ${ }^{5}$ Berdasarkan arti kedua (pernikahan) inilah yang paling populer digunakan oleh masyarakat Indonesia dalam menyebut "berpasangan" laki-laki dan perempuan secara resmi.

Secara terminologi, makna nikah menurut ulama mutaqaddimin berbeda dengan ulama mutaakhirin. Ulama mutaqaddimin menjelaskan bahwa nikah adalah akad yang ditetapkan oleh syara' bahwa seorang suami dapat memanfaatkan dan bersenangsenang dengan kehormatan seorang istri dan seluruh tubuhnya. ${ }^{6}$ Sedangkan ulama mutaakhirin berpendapat bahwa nikah berarti akad yang memberikan faedah hukum kebolehan mengadakan hubungan keluarga antara pria dan wanita dan mengadakan tolong-menolong serta memberi hak bagi pemiliknya dan pemenuhan kewajiban masing-masing. ${ }^{7}$ Dalam hal ini, para ulama berbeda pendapat tentang makna nikah dalam hal ini membagi ke dalam tiga golongan, yaitu:

Ulama Hanafiah berpendapat bahwa makna nikah secara hakiki adalah wata' (bersetubuh), sedangkan secara majazi bermakna akad. Pendapat ini didasarkan atas pemahaman mereka terhadap ayat dalam Q.S an-Nisa/4;22 yang berbunyi sebagai berikut;

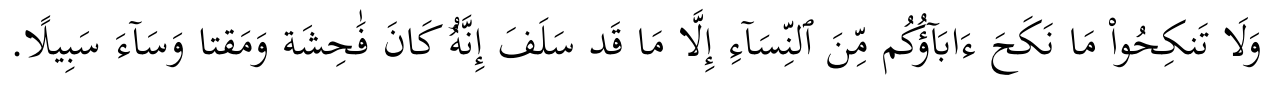

Terjemahnya:

Dan janganlah kamu kawini wanita-wanita yang telah dikawini oleh ayahmu, terkecuali pada masa yang telah lampau. Sesungguhnya perbuatan itu Amat keji dan dibenci Allah dan seburuk-buruk jalan (yang ditempuh). ${ }^{8}$

Ayat ini mengandung larangan bagi seorang anak untuk menikahi wanita yang telah dinikahi oleh ayahnya. Haram hukumnya menikahi perempuan-perempuan yang telah dinikahi oleh bapak kecuali terhadap perbuatan yang telah lalu sebelum turunnya ayat ini, maka hal itu dimaafkan oleh Allah. Allah melarang perbuatan tersebut karena sangat keji, bertentangan dengan akal sehat, sangat buruk karena dimurkai Allah dan sejahat-jahat jalan menurut adat istiadat manusia yang beradab.

Kata nikah dalam ayat tersebut menurut ulama Hanafiyah harus diartikan wata' bukan akad. ${ }^{9}$ Hazairin sependapat dengan golongan ini. Menurutnya inti suatu pernikahan adalah hubungan seksual, tidak ada pernikahan tanpa adanya hubungan seksual. Beliau mengambil tamsil antara suami dan istri, maka tidak perlu ada tenggang waktu menunggu (masa 'iddah) untuk menikah kembali bekas istri dengan laki-laki lain. ${ }^{10}$

Ulama Syafi'iyah dan Malikiyah berpendapat bahwa makna nikah secara hakiki adalah akad, sedangkan secara majazi bermakna wata'. Pendapat ulama ini didasarkan atas pemahaman terhadap ayat dalam QS al-Baqarah/2: 230, yang berbunyi, sebagai berikut;

\footnotetext{
${ }^{5}$ Departemen Pendidikan Nasional RI, Kamus Besar Bahasa Indonesia (Bandung: PT. Gramedia Pustaka Utama, 2002), h. 689.

${ }^{6}$ Muhammad Jamal Jamil, Korelasi Hukum Undang-Undang No. 1 Tahun 1974 tentang Pernikahan dan Inpres No. 1 Tahun 1991 tentang Kompilasi Hukum Islam (Makassar: Alauddin University Press, 2011), h. 16.

${ }^{7}$ Djaman Nur, Fikih Munakahat (Cet. I; Semarang: Toha Putra, 1993), h. 3.

${ }_{8}$ Departemen Agama, Alquran dan Tarjamahnya (Jakarta: Yayasan Penyelenggara Penterjemahan/Penafsir Alquran, 1971), h. 120.

${ }^{9}$ Muhammad Jamal Jamil....Korelasi, h. 17.

${ }^{10}$ Hazairin, Hukum Kekeluargaan Nasional Indonesia (Jakarta: Timtanas, 1961), h. 61.
} 


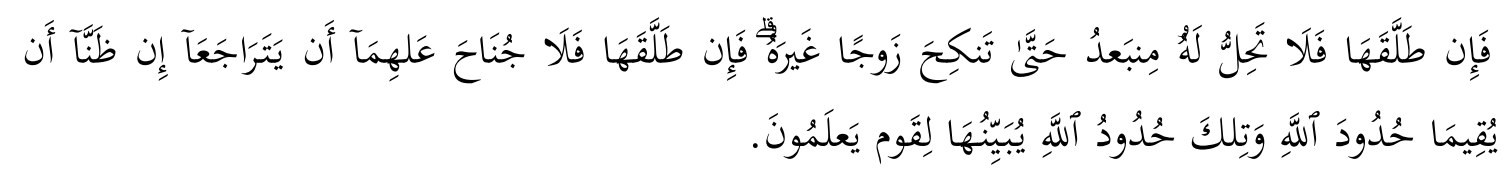

Terjemahnya:

Kemudian jika dia menceraikannya (setelah talak yang kedua), maka perempuan itu tidak halal lagi baginya sebelum dia menikah dengan suami yang lain. Kemudian jika suami yang lain itu menceraikannya, maka tidak ada dosa bagi keduanya (suami pertama dan bekas istri) untuk menikah kembali jika keduanyaberpendapat akan dapat menjalankan hukum-hukum Allah. Itulah ketentuan-ketentuan Allah yang diterangkan-Nya kepada orang-orang yang berpengetahuan. ${ }^{11}$

Ayat ini menerangkan, kalau sudah jatuh talak tiga, tidak boleh lagi rujuk. Apabila kedua belah pihak ingin hidup kembali sebagai suami- istri, maka perempuan itu harus kawin lebih dahulu dengan laki-laki lain, dan telah dicampuri oleh suaminya yang baru, dan kemudian diceraikan atas kehendak sendiri, dan sudah habis masa idahnya, barulah keduanya boleh rujuk kembali.

Ayat ini menyuruh untuk berhati-hati dalam menjatuhkan talak, jangan gegabah dan jangan terburu nafsu. Pikirkanlah masak-masak, karena terburu nafsu dalam menjatuhkan talak, akhirnya menyesal. Menjatuhkan talak itu dibolehkan dalam Islam, tapi ia adalah perbuatan yang dibenci Allah. Akibat perceraian itu besar sekali, baik bagi suami, lebih-lebih bagi istri dan anak-anak. Karenanya, apabila masih dalam talak kedua, lebih baik rujuk kembali, kalau memang masih bisa diharapkan terwujudnya rumah tangga bahagia, dan dapat menjalankan perintah Allah dengan sebaik-baiknya.

Di samping itu, ayat ini juga mengandung larangan bagi laki-laki berkumpul dengan istri yang ditalak tiga sampai ia menikah dengan laki-laki lain. Kata nikah dalam ayat tersebut menurut ulama golongan ini harus diartikan akad bukan wata' dengan alasan bahwa yang terkena qarinah dalam ayat tersebut adalah wanita, sebab wanita bukanlah pelaku dalam wata, ${ }^{12}$ Dalam kitab "Fathul Mu 'in" dijelaskan bahwa nikah menurut syara' ialah suatu akad (transaksi) yang intinya mengandung penghalangan wathi ' (persetubuhan) dengan memakai kata nikah atau kawin. Menurut pendapat yang sahih, pengertian hakiki dari nikah adalah akadnya, sedangkan secara majaz menunjukkan makna wathi, (persetubuhan). ${ }^{13}$

Jumhur ulama yang menggabungkan dua pendapat yang kontradiktif tersebut. Menurut jumhur ulama, jika ditelusuri maka akan ditemukan bahwa kata nikah terkadang digunakan dalam arti wata' dan terkadang pula digunakan dalam arti akad. Dengan demikian, kata nikah tidak dapat diartikan sebagai wata' atau akad saja sebab keduanya merupakan kata yang tidak dapat berdiri sendiri. Untuk itu, kata nikah seharusnya dimaknai dengan kesempatan yang dinyatakan dengan ucapan melalui ijab

\footnotetext{
${ }^{11}$ Kementerian Agama RI, Al-Qur'an dan Terjemahnya, h. 36.

${ }^{12}$ Muhammad Jamal Jamil, Korelasi......, h. 17.

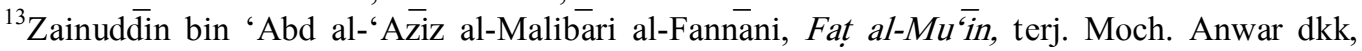
Terjemahan Fathul Mu’in, Juz II (Cet. VII; Bandung: Sinar Baru Algensindo, 2014), h. 1154.
} 
dan kabul antara wali dengan calon suami yang bertujuan untuk menghalalkan hubungan seksual (wata'). ${ }^{14}$

Perbedaan pendapat di antara para ulama tentang makna nikah, membawa implikasi hukum yang berbeda. Implikasi hukum yang dimaksud adalah apabila nikah diartikan sebagai wata', maka akibat hukumnya adalah haram bagi anak laki-laki yang mengawini wanita yang pernah disetubuhi oleh ayahnya secara tidak sah, atau sebaliknya. Oleh karena itu, seorang anak perempuan yang lahir dari hubungan gelap (zina) antara seorang laki-laki dengan seorang perempuan itu tidak boleh dikawini oleh laki-laki itu, karena bagaimanapun dia tetap anaknya. Meskipun secara yuridis ia tidak berhak memperoleh warisan dan perwalian dari laki-laki yang menghamili ibunya. Sebaliknya, apabila nikah diartikan akad, maka wanita yang disetubuhi secara tidak sah oleh seorang laki-laki, maka ia boleh dikawini oleh putra laki-laki tersebut. Bahkan laki-laki itu boleh mengawini anak dari hasil perzinaannya, jika yang dilahirkan anak perempuan. Hal ini disebabkan karena tidak ada hubungan nasab antara laki-laki pezina dengan anak tersebut.

Sementara kata أَسَرْرُ

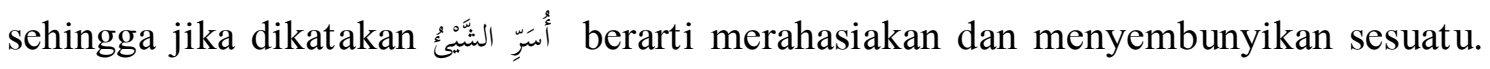
Ada juga yang berpendapat bahwa kata siri berasal dari kata infinitif سِرِ سِرِي Secara etimologi kata wِ wِ wِرِيُّ berarti diam-diam atau tertutup sementara secara rahasia, sembunyi-sembunyi dan misterius. ${ }^{15}$

Mengacu pada makna literal siri di atas, maka nikah siri berarti pernikahan yang dilakukan secara sembunyi-sembunyi atau rahasia. Dengan kata lain nikah siri adalah pernikahan yang dilakukan tanpa disaksikan oleh orang banyak dan tidak dilakukan di hadapan pencatat nikah, sekalipun demikian pernikahan ini dianggap sah oleh agama tetapi tidak dalam pandangan negara karena melanggar peraturan pemerintah. $^{16}$

Kata nikah siri terdiri dari dua suku kata, yaitu nikah dan siri Kata النكاح yang menurut bahasa artinya mengumpulkan, saling memasukkan, dan digunakan untuk arti bersetubuh (wathi). ${ }^{17}$ Kata النكاح juga dipergunakan untuk arti persetubuhan (coitus), juga untuk arti akad nikah. ${ }^{18}$ Bahkan kata "nikah" dapat didekati dari tiga aspek

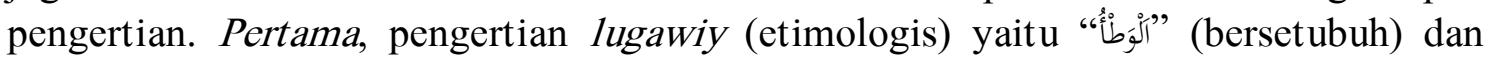

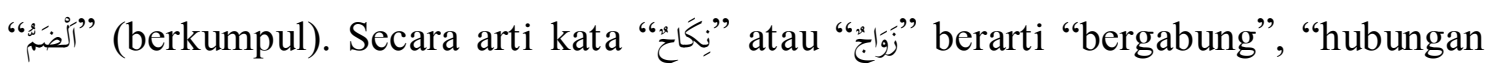

\footnotetext{
${ }^{14}$ Lili Rasyidi, Hukum Pernikahan dan Perceraian di Malaysia dan Indonesia (Cet. I; Bandung: Remaja Rosdakarya, 1991), h. 3.

${ }^{15}$ Mahmud Yusuf, Hukum Pernikahan dalam Islam (Jakarta: Hadakarya Agung), 1978), h. 176. Lihat juga Atabik Ali, Kamus Kontemporer Indonesia Arab. terj. Dari judul asli "Kamus al-Ashri Arabi Indonesia (tt: tp:, t.th), h. 1056.

${ }^{16}$ Dalam Peraturan Pemerintah Republik Indonesia No. 9 Tahun 1975 tentang Pelaksanaan Undang-Undang Nomor I Tahun 1974 tentang Pernikahan Pasal 2 sampai Pasal 9 yang menganut tentang pencatatan pernikahan. Pelanggaran tentang Peraturan Pemerintah ini telah diatur dan dituangkan dalam Pasal 45. Dalam Saidus Sahar, Undang-undang Pernikahan dan Masalah Pelaksanan Ditinjau dari Hukum Islam (Bandung: Alumni, 2009), h. 22.

${ }^{17}$ Abd.Rahman Gazaly, Fiqh Munakahat (Jakarta: Kencana, 2006), h. 7.

${ }^{18}$ Abddullah bin Nuh dan Umar Bakri, Kamus Arab Indonesia Inggris (Jakarta, Penerbit Mutiara, MCMLXXIV), h.132.
} 
kelamin", dan juga berarti "akad". ${ }^{19}$ Kedua, pengertian usüliy (syar'i), di antara argumentasi ulama berkaitan pengertian ini, yaitu dapat dilihat dari dua pengertian, yaitu pengertian hakikat (asal) dan pengertian majaz (kiasan). Pengertian hakikat adalah "al wat'u" (bersetubuh), sedangkan pengertian majaz adalah "aqad" (ikatan atau janji). Ketiga, pengertian fikih (hukum), bahwa sesungguhnya akad nikah itu adalah ketetapan Allah swt, yang menempatkan pasangan suami istri dapat mengambil manfaat atau kenikmatan dari kedua belah pihak. ${ }^{20}$

Adapun pengertian nikah siri dalam fikih kontemporer lebih dikenal dengan istilah nikah ' urfi (zawaj 'urfi). Nikah 'urfi adalah suatu pernikahan yang memenuhi syarat-syarat pernikahan tetapi tidak dicatat secara resmi oleh pegawai pemerintah yang menangani pernikahan. Dengan demikiam, dapat dipahami bahwa sebenarnya tidak ada perbedaan yang menonjol antara pernikahan syar'i dengan pernikahan 'urfi (nikah siri). Perbedaannya hanyalah antara resmi dan tidak resmi. Karena pernikahan 'urfi adalah sah dalam pandangan syar'i disebabkan terpenuhinya semua persyaratan nikah seperti adanya wali dan saksi, hanya saja belum dianggap resmi oleh pemerintah karena belum tercatat oleh pegawai KUA setempat sehingga mudah untuk digugat. Terkait dengan ini, maka setidaknya ada 3 bentuk atau model nikah siri yang dilakukan dalam masyarakat, yaitu:

Pertama, pernikahan antara seorang pria dengan seorang wanita yang sudah cukup umur yang dilangsungkan di hadapan dan dicatat oleh Pegawai Pencatat Nikah namun hanya dihadiri oleh kalangan terbatas keluarga dekat, tidak diumumkan dalam suatu resepsi. Kedua adalah pernikahan antara seorang pria dan seorang wanita yang masih di bawah umur yang menurut undang-undang, kedua-duanya masih bersekolah. Pernikahan ini atas inisiatif dari orang tua kedua belah pihak calon suami isteri yang sepakat menjodohkan anak-anak mereka dengan tujuan untuk lebih memastikan perjodohan dan menjalin persaudaraan yang lebih akrab. Biasanya setelah akad nikah mereka belum kumpul serumah dulu. Setelah mereka tamat sekolah dan telah mencapai umur pernikahan, lalu mereka dinikahkan lagi secara resmi di hadapan PPN. Ketiga adalah model pernikahan antara seorang pria dan seorang wanita yang sudah cukup umur menurut undang-undang akan tetapi mereka sengaja melaksanakan pernikahan ini di bawah tangan, tidak dicatatkan di KUA dengan berbagai alasan. Pernikahan ini mungkin terjadi dengan alasan menghemat biaya, yang penting sudah dilakukan menurut agama sehingga tidak perlu dicatatkan di KUA, atau mungkin, pernikahan itu dilakukan oleh seseorang yang mampu secara ekonomi, akan tetapi karena alasan tidak mau repot dengan segala macam urusan administrasi dan birokrasi sehingga atau karena alasan lain, maka ia lebih memilih nikah siri saja.

Sementara pengertian terminologi nikah siri dapat dipandang sebagai sebuah nomenklatur dalam khazanah hukum Islam dan sebenarnya telah dikenal di kalangan para ulama, setidaknya sejak zaman Imam Malik bin Anas. Hanya saja nikah siri yang dikenal pada masa lalu berbeda pengertiannya dengan nikah siri pada masa sekarang. Pada masa dahulu yang dimaksud dengan nikah siri, yaitu pernikahan yang memenuhi syarat dan rukunnya menurut syariat, namun tidak dipublikasikan dalam bentuk pesta atau walimah. Adapun nikah siri yang dikenal oleh masyarakat Islam Indonesia

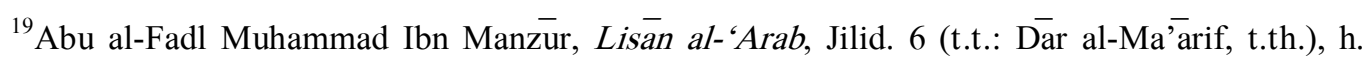
4537.

${ }^{20}$ Abdurrahman al-Jaziri, al-Fiqh ala al-Mazāhib al-Arba ‘ah, Jilid. 4 (Beirut-Libanon: Dàr alFikr, 1989), h. 1-2
} 
sekarang ialah pernikahan yang dilakukan menurut hukum Islam, tetapi tidak dilakukan di hadapan PPN dan atau tidak dicatatkan di Kantor Urusan Agama, sehingga tidak memperoleh akte nikah sebagai satu-satunya bukti legal formal.

Bentuk-bentuk pernihan siri ini ditegaskan kembali oleh Nurhadi dalam bukunya yang berjudul "Nikah di Bawah Tangan" di mana disebutkan beberapa konsep nikah siri yang dijelaskan oleh ulama, yaitu nikah siri merupakan jenis pernikahan di mana akad dan transaksis antara laki-laki dan perempuan dan tidak dihadiri oleh para saksi, tidak dipublikasikan dan tidak tercatat secara resmi dan pasangan suami istri tersebut hidup secara sembunyi-sembunyi, sehingga tidak ada orang mengetahuinya kecuali mereka berdua. $^{21}$

Konsep pernikahan dalam agama Islam tetapi tidak dicatat oleh petuga pemerintah, baik petugas pencatat nikah maupun Kantor Urusan Agama dan tidak diplikasikan, sehingga pernikahan umum dan pernikahan siri dapat dibedakan secara tegas. Nikah siri model yang kedua ini dianggap sah karena secara fikih semua syarat dan rukunya terpenuhi. Konsep lain menyebutkan bahwa nikah siri adalah suatu pernikahan yang mengikuti ketentuan agama Islam dan tercatat oleh pegawai pencatat nikah atau Kantor Urusan Agama (KUA) akan tetapi belum mengalami resepsi atau peneriamaan secara terbuka. Sekalipun demikian, nikah siri tetap memberitahukan dan menyampaikan kepada keluarga terdekat atau sebagian tetangga. ${ }^{22}$

Berdasarkan pembagian konsepsi nikah siri tersebut Fauzil Adhim menyimpulkan bahwa ada dua konsepsi nikha siri yang berkembang di dalam masyarakat, yaitu; Pertama, nikah siri adalah pernikahan yang biasa terjadi di masyarakat hanya saja tidak tercatat pada Kantor Urusan Agama. Pernikahan ini tetap sah menurut agama tetapi tidak memiliki legalitas formal yang berfungsi sebagai perlindungan hukum bila sewaktu-waktu terjadi masalah. Kedua, nikah siri adalah pernikahan yang benar-benar rahasia tanpa ada wali dan saksi dan tidak adal walimah yang berfungsi sebagai pengumuman kepada masyarakat. ${ }^{23}$

Pengertian lain menyebutkan bahwa pernikahan siri adalah pernikahan yang memenuhi ketentuan hukum Islam secara materil sebagai mana yang dimaksud dalam Pasal 2 ayat 1 UU No. 1 tahun 1974 tetapi tidak memenuhiketentuan pencatatan sebagai syarat formil yang diatur dalam Pasal 2 ayat (2) UU No. 1 tahun $1974 .{ }^{24}$ Sebenarnya, antara nikah siri dan nikah di bawah tangan ada perbedaan. Nikah siri adalah seperti yang dijelaskan di atas, sedangkan nikah di bawah tangan adalah nikah tanpa adanya suatu pencatatan pada instansi yang telah ditentukan oleh peraturan perundang-undangan, yaitu Kantor Urusan Agama (KUA) bagi yang beragama Islam, dan Kantor Catatan Sipil bagi yang non muslim. Istilah nikah di bawah tangan timbul setelah berlakunya Undang-Undang RI Nomor 1 Tahun 1974 yang secara efektif berlaku pada tahun 1975 .

Dalam fikih Maliki, nikah siri diartikan sebagai nikah yang atas pesan suami, para saksi merahasiakannya untuk istrinya atau jamaahnya, sekalipun keluarga

\footnotetext{
${ }^{21}$ M. Quraish Shihab, Perempuan (Jakarta: Lentera Hati, 2005), h. 215.

${ }^{22}$ Ahsin Muammar, Nikah Bahwah Tangan Versi Anak Kampus (Jakarta: Qultum Media, 2005), h. 19 .

${ }^{23}$ Muhammad Fauzil Adhim, Indahnya Pernikahan Dini (Jakarta; Gema Insani Press, 2002), h. 187-188

${ }^{24}$ Idris Ramulyo, Hukum Pernikahan Islam, Suatu Analisis dari UU No. 1 yang 1974 dan Kompilasi Hukum Islam (Jakarta: Bumi Akasara, 2004), h. 239.
} 
setempat. Selanjutnya dikatakan bahwa Mazhab Maliki tidak membolehkan nikah siri, nikahnya dapat dibatalkan dan pelakunya dapat diancam dengan had berupa cambuk atau rajam. Mazhab Syafi'i dan Hanafi juga tidak memperbolehkan nikah siri. ${ }^{25}$ Khalifah Umar bin Khatthab, memerintahkan untuk mempublikasikan pernikahan sebagai bentuk perlindungan terhadap kehormatan, dan pernah mengancam pelaku nikah siri dengan hukuman had. ${ }^{26}$

Wildan Suyuti Mustofa menjelaskan, sebagaimana yang dikutip oleh H.M. Anshary MK, bahwa dari pengamatan di lapangan, bahwa nikah siri dapat dibedakan kepada dua jenis. Pertama, akad nikah yang dilakukan oleh seorang laki-laki dan seorang perempuan tanpa hadirnya orang tua/wali si perempuan. Dalam pernikahan bentuk pertama ini akad nikah hanya dihadiri oleh laki-laki dan perempuan yang akan melakukan akad nikah, dua orang saksi dan guru atau ulama yang menikahkan tanpa memperoleh pendelegasian dari wali nikah yang berhak. Padahal guru atau ulama tersebut dalam pandangan hukum Islam tidak berwenang menjadi wali nikah, karena ia tidak termasuk dalam prioritas wali nikah. ${ }^{27}$ Kedua, adalah akad nikah yang telah memenuhi syarat dan rukun suatu pernikahan yang legal sesuai dengan ketentuan hukum Islam, tetapi tidak dicatatkan sesuai dengan ketentuan Undang-Undang Pernikahan di Indonesia. ${ }^{28}$

Abdul Gani Abdullah mengatakan, yang dikutip oleh H.M. Anshary MK, bahwa untuk mengetahui apakah pada suatu pernikahan itu terdapat unsur siri atau tidak, dapat dilihat dari tiga indikator yang harus selalu menyertai suatu pernikahan legal. Apabila salah satu faktor saja tidak terpenuhi, pernikahan itu dapat diidentifikasi sebagai pernikahan siri. Tiga indikator itu adalah; Pertama, subyek hukum akad nikah, yang terdiri dari calon suami, calon istri, dan wali nikah adalah orang yang berhak sebagai wali, dan dua orang saksi. Kedua, kepastian hukum dari pernikahan tersebut, yaitu ikut hadirnya Pegawai Pencatat Nikah pada saat akad nikah dilangsungkan, dan Ketiga, walimatul 'urusy, yaitu suatu kondisi yang sengaja diciptakan untuk menunjukkan kepada masyarakat luas bahwa di antara kedua calon suami istri tadi telah resmi menjadi suami istri. Pada indikator ketiga inilah letak hakikat filosofis dari hadis Rasulullah saw tersebut. ${ }^{29}$

Melihat indikator yang dikemukakan oleh Prof. Dr. A. Gani Abdullah, SH. yang dikutip oleh H.M. Anshary MK di atas, untuk dapat mengidentifikasi apakah suatu pernikahan itu merupakan pernikahan siri atau pernikahan legal, istilah pernikahan di bawah tangan yang sebenarnya merupakan istilah lain dari nikah siri. Hal itu karena, dari ketiga unsur yang harus ada pada suatu pernikahan logis yang diakui oleh hukum tersebut di atas, ada unsur-unsur yang tidak terpenuhi di dalam pernikahan di bawah tangan. ${ }^{30}$ Unsur yang tidak terpenuhi itu setidak-tidaknya adalah unsur kedua

\footnotetext{
${ }^{25}$ Lihat Wahbah al-Zuhāili, al-Fiqh al-Isläm wa Adillatuhu, Jilid 7 (Beirut: Dār al- Fikr, 1991), h , h. 71 .

${ }^{26}$ Lihat Muhammad 'Abdul 'Az̄iz al-Halawi, Fatawa wa Aqdiyah Amīil Mukminīn 'Umar ibn al-Khattāb, terj. Zubeir Suryadi Abdullah, Fatwa dan Ijtihad Umar bin Khattab; Ensiklopedia Berbagai Persoalan Fiqih (Cet. I; Surabaya: Risalah Gusti, 1999), h. 170.

${ }^{27}$ M. Anshary, Hukum....., h. 25.

${ }^{28}$ M. Anshary ...., h. 26.

${ }^{29}$ M. Anshary,.... h. 26.

${ }^{30}$ Istilah pernikahan di bawah tangan muncul setelah diberlakukannya secara efektif UndangUndang Nomor 1 Tahun 1974 tentang Pernikahan. Pernikahan di bawah tangan yang disebut juga sebagai pernikahan liar pada prinsipnya adalah pernikahan yang menyalahi hukum, yakni pernikahan
} 
dan ketiga, yaitu pernikahan tersebut tidak dicatatkan pada Pegawai Pencatat Nikah dan tidak diumumkan kepada masyarakat luas. ${ }^{31}$

Terkait dengan ini, Neng Djubaidah, S.H., M.H., mengatakan bahwa pengertian "perkawinan tidak dicatat" adalah berbeda dengan "perkawinan sirri", bahwa yang dimaksud dengan "perkawinan tidak dicatat adalah perkawinan yang memenuhi rukun dan syarat sesuai dengan hukum Islam, tetapi tidak dicatatkan atau belum dicatatkan di Kantor Urusan Agama Kecamatan, sebagai Unit Pelaksana Teknis Dinas (UPTD) Instansi Pelaksana di wilayah Kecamatan setempat, ${ }^{32}$ sebagaimana ditentukan dalam Undang-Undang Nomor 23 Tahun 2006 tentang Administrasi Kependudukan. $^{33}$

Istilah "tidak dicatat" tidak sama dengan istilah "tidak dicatatkan". Kedua istilah tersebut mengandung makna yang berbeda. Pada istilah "perkawinan tidak dicatat" bermakna bahwa perkawinan itu tidak mengandung unsur "dengan sengaja" yang mengiringi niat seseorang untuk tidak mencatatkan perkawinannya. Adapun istilah "perkawinan tidak dicatatkan" terkandung niat buruk dari suami, khususnya yang bermaksud perkawinannya memang "dengan sengaja" tidak dicatatkan. Oleh karena itu "Perkawinan tidak dicatat" dengan "perkawinan yang belum dicatatkan" dapat disepadankan, yang berbeda dengan "perkawinan tidak dicatatkan".34

\section{METODOLOGI PENELITIAN}

Penelitian ini adalah penelitian deskriptif kualitatif untuk menggambarkan kondisi faktual dari kecenderungan masyarakat Sulawesi Barat dalam melakukan nikah siri. Penelitian ini dilakukan di Sulawesi Barat yang meliputi tiga Kabupaten kota, yaitu Mamuju, Mejene dan Polman. Pendekatan yang digunakan adalah pendekatan yuridis normative, fenomenologis, filosofis, dan sosiologis. Penelitian ini menggunakan data primer yang diambil dari sumber-sumber utama, yaitu para responden yang terdiri dari pelaku nikah siri, pejabat desa, pejabat KUA, dan pejabat Pengadilan yang berkompeten menjawab penelitian tentang nikah siri. Data sekunder diambil dari sumber-sumber lain, yaitu tulisan-tulisan yang terkait dengan formulasi hukum nikah siri dan buku-buku tentang sosiologi hukum dan filsafat hukum Islam sebagai alat pembedah terhadap penelitian ini. Data dikumpulkan dengan metode wawancara dan observasi dengan instrumen pedoman wawancara. Data diolah dan dianalisis dengan reduksi data, penyajian data, penarikan kesimpulan atau verifikasi. Keabsahan data diuji dengan triangulasi.

\section{HASIL PENELITIAN DAN PEMBAHASAN}

yang dilakukan di luar ketentuan hukum pernikahan yang berlaku secara positif di Indonesia. Selanjutnya, oleh karena pernikahan di bawah tangan tidak mengikuti aturan hukum yang berlaku, pernikahan semacam itu tidak mempunyai kepastian dan kekuatan hukum dan karenanya, tidak pula dilindungi oleh hukum. Lihat M. Anshary ..... h. 27

${ }^{31}$ M. Anshary, ..... h. 27.

${ }^{32}$ Lihat Neng Djubaidah, Pencatatan Perkawinan dan Perkawinan Tidak Dicatat Menurut Hukum Tertulis di Indonesia dan Hukum Islam, h. 10.

${ }^{33}$ Lihat Republik Indonesia, Undang-Undang Nomor 23 Tahun 2006 tentang Administrasi Kependudukan, Pasal 8.

${ }^{34}$ Djubaidah, Pencatatan Perkawinan.... h. 11. 
Berdasarkan hasil wawancara dan penelusuran peneliti terhadap beberapa lokasi penelitian di Sulawesi Barat, maka ditemukan beberapa sebab terjadinya nikah siri di kalangan masyarakat, antara lain adalah;

\section{Faktor Adanya Perubahan Sosial}

Perubahan sosial merupakan fakta sosial dalam kehidupan masyarakat yang timbul dan dilakukan disebabkan adanya bentuk-bentuk perubahan sosial yang diakibatkan oleh masyarakat. Perubahan ini dapat menimbulkan dampak negatif di satu sisi dan dampak positif di sisi lain, tergantung bagaimana struktur sosial itu berpengaruh dalam masyarakat. Dampak positif perubahan sosial antara lain dapat menumbuh-kembangkan pengetahuan dan wawasan dalam masyarakat senmentara dampak negatifnya dapat mengurangi bahkan menghilangkan nilai-nilai yang telah ada dalam masyarakat.

Dalam kaitannya dengan nikah siri, maka sebab terjadinya nikah siri dalam masyarakat, khususnya masyarakat Islam di Sulawesi Barat disebabkan oleh berbagai faktor di mana faktor-faktor sosial tersebut berkembang dan memberi pengaruh kepada masyarakat, sehingga faktor itu dilakukan dengan sengaja secara berkesinambungan. Di antara fakta-fakta sosial yang terjadi di Sulawesi Barat antara lain adalah;

Kasus terjadinya pernikahan nikah siri di Kantor Urusan Agama (KUA) Cendana di mana seorang wanita telah melangsungkan pernikahannya secara siri di mana pelaku nikah siri ini belum sempat bercerai tetapi si perempuan ingin menikah lagi dengan seorang laki-laki, sehingga pelaku nikah siri ini kebingungan terhadap isbat nikahnya, lalu si pelaku nikah siri itu meminta agar pencatatan nikahnya tersebut dicatat untuk pernikahannya yang sekarang dan meminta agar pernikahan sirinya yang terdahulu dianggap tidak pernah terjadi, maka dalam kasus ini penetapan isbat nikahnya oleh Pengadilan Agama mengalami catat hukum. ${ }^{35}$

Penyebab lain adalah adanya stigma dalam masyarakat Sulawesi Barat yang memahami bahwa agama membolehkan nikah siri dan hanya orang-orang yang kurang paham agama yang menolak nikah siri. Perbedaan antara nikah siri dengan pernikahan yang bukan nikah siri itu hanya persoalan hukum positif, padahal hakikat pernikahan itu adalah menghalalkan hubungan laki-laki dan perempuan dan aka menimbulkan hak dan kewajiban antara kedua pasangan suami istri tersebut, sepanjang kewajiban seorang laki-laki itu dilaksanakan dengan baik demikian pula kewajiban seorang wanita dilaksanakan dengan baik, maka itulah yang diharapkan dalam pernikahan, dan tidak ada jaminan bahwa orang yang menikah hanya dengan satu istri dijamin sudah bisa hidup bahagia dan lebih sejahtera dibanding orang yang punya istri lebih dari satu dan tidak ada jaminan kebahagian dan kesejahteraan itu didapatkan dengan hanya mempunyai satu orang istri, apalagi banyak fakta dalam masyarakat bahwa seorang laki-laki yang mempunyai satu istri hidupnya lebih menderita, tidak akur, tidak juga menjalankan apa yang disyariatkan oleh Allah Swt. Sebaliknya, ada banyak orang yang menerapkan nikah nikah siri tetapi mereka bisa hidup aman dan damai karena intinya adalah bagaimana seorang suami atau istri bisa menjalankan kewajiban dan tanggung jawab masing-masing. ${ }^{36}$

\footnotetext{
${ }^{35}$ M. Sahid, Kepala Kantor Urusan Agama (KUA) Banggae. Wawancara, Majene, 20 Oktober 2017.

${ }^{36}$ Syamsuddin, Anggota DPR Kabupaten Mamuju, Pelaku Nikah Siri. Wawancara; Mamuju, 17 November 2017.
} 
Fakta lainnya adalah bahwa nikah siri di masyarakat Sulawesi Barat didasari oleh dua faktor teologis, yaitu; Pertama, ada yang menganalogikan bahwa pernikahan siri itu ialah yang tidak ternyatat di Kantor Urusan Agama (KUA). Kedua, pernikahan siri itu adalah seorang laki-laki membawa atau melarikan anak orang yang pergi ke Imam dengan membawa lari ke imam untuk menikah, sebagaimana yang terjadi di lingkungan Paccamboang Kecamatan Banggae, Kabupaten Majene. Jika seorang lakilaki membawa anak gadis masuk ke dalam lingkungan Paccaboang maka oleh imam lingkungan itu langsung menikahkan kedua pasangan tersebut. Model pernikahan seperti ini tidak sah menurut syariat karena tidak ada walinya, model pernikahan seperti ini biasanya perwaliannya jatuh kepada wali hakim dalam hal ini sebagai wali adalnya yang diwakili oleh imam yang menikahkannya. Di sisi lain, disebutkan bahwa aturan hukum wali adal itu adalah pemerintah setempat dalam hal ini lembaga pengadilan yang memiliki kewenangan dalam hal penetapan hukum perkawinannya, Fenomena nikah seperti ini tidak termasuk kedalam kategori nikah siri oleh karena pernikahan siri yang diartikan secara sembunyi-sembunyi yang sah menurut syariat bahkan pihak orang tuanya menyetujui pernikahan itu hanya saja tetapi tidak terdaftar di kantor KUA. ${ }^{37}$

Fakta berikutnya adalah bahwa terjadinya nikah siri di Sulawesi Barat Binuang adalah karena alasan kondisional, yaitu suatu kondisi di mana seseorang butuh untuk menikah berdasarkan batasan umur yang telah ditetapkan oleh undang-undang namun karena alasan kecelakaan atau dalam istilah orang Mandar dikenal dengan istilah kande dulu baca undi atau hamil di luar nikah, sehingga mereka terdesak untuk menikah secara terpaksa, dengan kata lain pernikahannya adalah pernikahan terpaksa yang tidak tercatat di Kantor Urusan Agama (KUA) atau tidak mendapatkan buku nikah disebabkan karena mereka malu diketahui oleh masyarakat, sehingga mereka terpaksa melakukan nikah siri. ${ }^{38}$

Fakta lain adalah bahwa nikah siri yang terjadi dalam masyarakat Sulawesi Barat merupakan perkara yang belum dipamahi secara menyeluruh oleh masyarakat, bahkan sebagian masyarakat ada yang memahami bahwa nikah siri itu sebagai bentuk penjajahan terhadap wanita, hal ini disebabkan oleh kurangnya sosialisasi terhadap masyarakat. Faktor lainnya adalah persoalan legalitas nikah siri dalam syariat, di mana syariat mendorong bahwa bagi laki-laki maupun perempuan yang mampu dipersilahkan untuk melakukan nikah siri seperti anjuran Alquran yang menyebutkan batasan minimal dan maksimal dalam menikah dimulai dari dua kali, tiga kali sampai empat kali menikah, apakah pernikahan dalam bentuk poligami (tercatat) atau pernikahan poligami tidak tercatat atau nikah siri. ${ }^{39}$ Dengan demikian, dapat ditegaskan bahwa nikah siri boleh karena murni ajaran Islam karena telah memenuhi syarat dan rukun sebuah pernikahan.

\section{Faktor Lingkungan dan Keluarga}

Faktor lingkungan dan keluarga menjadi salah satu sebab terjadinya nikah siri di Sulawesi Barat, sebagaimana yang dikemukakan oleh Kepala Kantor Urusan Agama

\footnotetext{
${ }^{37}$ Abdul Haris Nawami, Kepala Kantor Urusan Agama (KUA) Kecamatan Binuang. Wawancara; Polewali Mandar, 24 Desember 2017.

${ }^{38} \mathrm{AHN}$, Wawancara; 2017.

${ }^{39}$ Sabir, Kepala Kantor Urusan Agama (KUA) Tappalang Barat. Wawancara; Mamuju, 17 November 2017.
} 
(KUA) Binuang yang mengatakan bahwa ada dua faktor utama yang menyebabkan terjadinya nikah siri di Sulawesi Barat adalah penyebab lingkungan dan penyebab keluarga. Untuk meminimalisir nikah siri ini harus dimulai dengan diri sendiri dan keluarga yaitu dengan cara memberi nasehat dan arahan kepada masyarakat. Data statistik di daerah Polewali Mandar menunjukkan bahwa jumlah perempuan lebih banyak dari jumlah laki-laki, sehingga jika digunakan skala perbandingan, maka tentunya ada perempuan yang tidak dapat bagian pasangan nikah atau tidak menikah. Menjawab fakta ini, Kepala Kantor Urusan Agama (KUA) Binuang mengatakan bahwa hal seperti itu tidak perlu terjadi jika setiap pelaku nikah siri memahami UndangUndang Perkawinan No. 1 Tahun 1974 di mana di dalamnya disebutkan bahwa seorang laki boleh menikah lebih dari satu yang penting mendapatkan dispensasi dari Pengadilan Agama dan yang bersangkutan memenuhi syarat untuk menikah. Memang, ada istilah di kalangan perempuan dalam masyarakat termasuk di Sulawesi Barat bahwa perempuan cenderung untuk tidak diduakan bahkan mereka mengatakan kepada suami mereka yang ingin menikah lagi untuk melangkahi dulu mayatku jika ingin beristri lagi. Karena itu, menurut Kepala Kantor Urusan Agama (KUA) bahwa fakta seperti itu sifatnya kasuistik karena pada kenyataannya dalam masyarakat Sulawesi Barat tidak sedikit perempuan yang siap untuk dimadu hanya saja pihak laki-laki harus mendapatkan legalitas dari negara berupa izin dari pengadilan untuk berpoligami dan ini yang tidak tersosialsasi di masyarakat, sehingga mereka mengangpnya dilarang untuk menikah lebih dari satu. ${ }^{40}$

Alasan berikutnya adalah karena perlakuan dan perbuatan seorang suami yang melakukan pernikahan tanpa seizin istrinya, dan kasus seperti ini banyak terjadi dalam masyarakat di Sulawesi Barat, seperti kasus yang pernah ia tangani di mana ada seorang laki-laki yang telah pisah ranjang dengan istirnya yang dalam sigat ta'liq talaq disebutkan bahwa dalam jangka 2 tahun tanpa informasi atau pisah ranjang maka jatuh talak satu. Kasus lain yang pernah ia tangani adalah bahwa ada seorang suami berangkat ke Malaysia untuk berkeja tetapi di perantauan ia menikah lagi dan pihak istri mengetahui bahwa suaminya telah menikah di Malaysia dan sang istripun tidak mau kalah, dan iapun menikah di kampung karena ia beranggapan bahwa kalau suaminya bisa menikah di rantau iapun bisa menikah di kampung. ${ }^{41}$

\section{Faktor Kurangnya Harmonisasi dalam Keluarga}

Sementara dalam perspektif penghulu, penyebab nikah siri antara lain disebabkan oleh tidak adanya keharmonisan dalam rumah tangga. Kedua, memang ada orang yang menikah siri bukan disebabkan karena persoalan keharmonisan tetapi terlalu kasar jika dikatakan bahwa sudah menjadi hobi atau merasa senang dan menjadi kebanggaan jika seseorang melakukan nikah siri. Ketiga, berdasarkan prosentasi angka perceraian di Sulawesi Barat yang mencapai 70\% lebih dan setelah ditelusuri maka didapatkan data bahwa penyebab utama perceraian di Sulawesi Barat itu lebih dominan dilakukan dengan cerai gugat, artinya pihak istri yang mengajukan perceraian di Pengadilan Agama. Prosentasi penyebab perceraian tersebut menurut Kepala Kantor Urusan Agama (KUA) tersebut disebabkan oleh faktor disharmonisasi yang mencapai

\footnotetext{
${ }^{40}$ AHN, Wawancara, 2017.

${ }^{41}$ HKR. Wawancara, 2017.
} 
$35 \%$, sementara faktot atau alasan ekonomi mencapai $18 \%$ dan sisanya sebanyak $8 \%$ disebabkan oleh pihak ketiga atau alasan perselingkuhan. ${ }^{42}$

Menurut salah seorang tokoh agama yang tidak ingin disebutkan namanya, ia mengatakan bahwa di masyarakat kita sering terjadi pernikahan tidak tercatat atau nikah siri salah satu faktornya adalah karena ingin menikah 2 kali sementara tidak melewati jalur yang telah ditentukan oleh aturan no 1 tahun 1971 bahwa pernikahan itu lebih dari satu harus lewat pegadilan secara terbuka, persolaannya dalah ada tidak perempuan yang mau meleewati sidang tersebut. kedua, persoalan di madu meruapakan sesuatu yang sangat berat, maka sebaeian orang melaukan jalan pintas dengan nikah $\operatorname{siri}^{43}$

Sementara itu, salah seorang pelaku nikah siri di Majene yang bernama Bapak Syamsuddin mengatakan bahwa sebab ia melakukan nikah siri adalah karena tidak adanya rekomendasi dari istri pertama, sehingga suami nekad melakukan nikah siri. Penyebab kedua adalah kurangnya pemahaman istri terhadap kebutuhan suami, sehingga ada di antara istri yang melarang suaminya menikah lagi. Dikatakan sebagai kurangnya pemahamaan oleh karena ada sebagian istri yang mengizinkan atau merekomendasikan atau memberikan peluang kepada suamiya untuk menikah lagi oleh karena sang istri tersebut paham keadaan suami dan paham agama. Faktor lain adalah karena masyarakat enggan melaporkan pernikahan sirinya ke Kantor Urusan Agama (KUA) karena tidak ingin diketahui orang lain, dan tidak ingin diketahui istri pertama atau kedua serta alasan malu jika harus berurusan dengan Kantor KUA. ${ }^{44}$

\section{Faktor Kebutuhan Seksualitas/Biologis}

Seks adalah unsur badani atau biologis perempuan dan laki-laki yang sering disebut dengan jenis kelamin sedangkan seksualitas adalah menyangkut berbagai dimensi yang sangat luas yakni dimensi biologis, dimensi sosial dan dimensi psikologis serta dimensi kultural. Pemenuhan kebutuhan seksual merupakan salah satu kebutuhan dasar manusia yang harus di penuhi setiap manusia. Di dalam masyarakat bebas, seseorang dapat menyalurkan kebutuhan seksualnya sesuai dengan keinginan dan orientasi seksual yang dimilikinya oleh para pelaku nikah siri dalam masyarakat di Sulawesi Barat.

Menurut salah seorang informan yang tidak mau disebutkan namanya bahwa penyebab lain terjadinya nikah siri di Sulawesi Barat adalah karena persoalan adanya kebutuhan nafkah batin seorang wanita, sehingga ia ikhlas untuk dijadikan istri siri. Alasanya adalah bahwa sebagai wanita ia telah memiliki segalanya sehingga yang ia butuhkan hanya nafkah batin saja, bahkan menurut salah seorang pejabat Kantir Urusan Agama (KUA) di Sulawesi Barat yang tidak mau disebutkan identitasnya mengatakan bahwa ia berapa kali ditawari oleh seorang janda kaya mantan pejabat salah satu BUMN di Kabuaten Pangkep beranak satu menawari dirinya untuk menjadi istri sirinya, sebagai janda muda yang kaya yang ia butuhkan hanya kebutuhan atau nafkah batin saja, bahkan ia mau memberikan dan menjamin hidup responden tersebut yang penting ia bersedia menjadi suami sirinya. Pada kesempatan lain, respoden tersebut menceritakan pengalamannya yang sering diajak menjadi suami siri dari salah

\footnotetext{
${ }^{42}$ Kasman Hamal, Kepala Kantor Urusan Agama (KUA) Kecamatan Mamuju. Wawancara; Mamuju, 29 November 2017

${ }^{43}$ Bukhari. Tokoh Agama/ Pengulu Polewali Mandar. Wawancara; 15 Desember 2017.

${ }^{44}$ Syamsuddin. Wawancara, 2017.
} 
satu pegawai bank, alasan pegawai bank tersebut adalah bahwa sebagai pegawai bank yang mengejar target pekerjaan dia sangat membutuhkan akses pekerjaan yang lancar yang dapat diberikan oleh respondenya tersebut.

\section{Faktor Ekonomi}

Masalah Ekonomi adalah masalah yang sering terjadi dalam kehidupan sehari hari baik masalah dalam jual beli, tawar menawar ataupun bentuk transaksi lainnya apakah bermotif agama atau bukan. Dalam kehidupan sekarang terutama di Indonesia terdapat beberapa masalah ekonomi yang terjadi diantaranya adalah persoalan dalam rumah tangga di mana terjadi berbagai persoalan antara suami dan istri, terjadi hubungan antara orang tua kepada anaknya yang semuanya dilatarbelakangi oleh persoalan ekonomi. Salah satu aspek yang mendominasi hubungan antara laki-laki dan perempuan dalam menata dan mengikat hubungan dalam perkawinan adalah masalah ekonomi bahkan fenomena yang terjadi dala sebuah pernikahan siri salah satu penyebabnya adalah pertimbangan ekonomi.

Menurut Kepala Kantor Urusan Agama (KUA) Binuang, dewasa ini banyak perempuan yang membutuhkan laki-laki mapan sebagai pendamping hidupnya, bukan semata-mata karena kebutuhan batin yang ia cari, seperti yang ia alami sendiri bahwa ada perempuan yang rela dinikahi secara siri karena alasan nafkah lahir. Sebagai kepala KUA, ia sudah tiga kali ditelpon oleh perempuan yang berbeda untuk mengajaknya menikah siri agar wanita-wanita itu mendapatkan nafkah lahir darinya. Karena itu, alasan nafkah batin yang dibutuhkan seorang perempuan sifatnya kasuistik apalagi seorang laki-laki yang telah berusia 40 tahun ke atas tidak bisa lagi memberikan nafkah batin secara maksimal kepada istri yang masih muda dan hampir $90 \%$ perempuan muda yang mau dinikahi secara poligami atau siri yang telah berumur cenderung mengincar harta laki-laki tersebut. ${ }^{45}$

\section{Faktor Tradisi dan Budaya}

Tradisi merupakan kebiasaan yang turun temurun dan menjadi bagian dari kehidupan suatu kelompok masyarakat kemudian membudaya, sehingga menjadi suatu cara hidup yang berkembang dan dimiliki bersama oleh sebuah kelompok orang lalu diwariskan dari generasi ke generasi. Dalam masyarakat umum persoalan pernikahan tidak dapat dilepaskan dari tradisi dan budaya yang berada pada suatu daerah di mana pernikahan itu dilangsungkan, karena alasan tradisi dan budaya ini pula yang menjadikan fenomena nikah siri di Sulawesi Barat banyak terjadi di kalagan masyarakat karena adanya pandangan yang telah membusaya bahwa buku nikah tidaklah penting bagi mereka. Hal ini sesuai dengan pandangan yang dikemukakan oleh Kepala Kantor Urusan Agama (KUA) Campalagiang yang mengatakan bahwa alasan terjadinya nikah siri di Sulawesi Barat adalah karena para pelaku nikah siri itu menganggap bahwa buku nikah itu tidak penting, padahal urgensi buku nikah itu berkaitan langsung dengan segala urusan keperdataan seseorang, ini dibuktikan dengan adanya logo Garuda pada buku nikah tersebut, sebagai lambang penyelenggaraan administrasi negara Republik Indonesia.

Masih menurut Kepala Kantor Urusan Agama (KUA) Campalagiang, ia mengatakan bahwa penyebab lain nikah siri di Sulawesi Barat disebabkan kurangnya sosialisasi terhadap pentingnya pencatatan dan pentingnya buku nikah tersebut, di

\footnotetext{
${ }^{45} \mathrm{AHN}$, Wawancara, 2017.
} 
samping karena adanya faktor keyakinan dan kesadaran masyarakat yang kurang untuk mencatatkan perkawinannya, ditambah adanya tipologi dalam masyarakat yang sangat normatif, di mana sejak 5 tahun sampai 10 tahun yang lalu, masyakarat tidak menyadari pentingnya buku nikah tersebut. Kondisi sosial masyarakat Sulawesi Barat yang secara normatif meyakini bahwa nikah siri itu tidak salah juga menjadi penyebab terjadinya nikah siri karena masyarakat mengetahui bahwa $90 \%$ regulasi tentang hukum perkawinan tersebut berasal dari intisari hukum syariat, di mana syarat dan rukun pernikahan yang mereka lakukan itu sah secara hukum syariat tetapi tidak sah berdasarkan hukum positif karena ada aturan yang tidak dipenuhi, yaitu pencatatan. Hal ini disebabkan oleh karena aturan perkawinan di Indonesia harus merujuk kepada Kompilasi Hukum Islam (KHI) dan Undang-Undang No. 1 Tahun 1974, sebagai hukum positif $^{46}$

Selain itu, adanya kebiasaan masyarakat yang masih sering melakukan pernikahan di bawah umur. Mereka melakukan nikah siri ini disebabkan karena mereka kurang memahami aspek kesehatan alat reproduksi wanita, sehingga dapat berdampak buruk pada saat mereka hamil muda bahkan menimbulkan resiko kemamtian pada saat melahirkan anaknya. Kebanyakan pelaku nikah siri di bawah umur melakukan nikah siri karena alasan fantasi seksual yang menggelora dan memiliki hasrat besal untuk menikmati seks di usia muda mereka. Alasan lainnya menurut bapak KUA adalah karena persoalan akses di mana masyarakat, kebanyakan nika siri terjadi di Sulawei Barat karena mereka berada di daerah terpencil, sehingga masyarakat tidak memiliki akses untuk mendaftarkan atau melaporkan perkawinannya ke Kantor Urusan Agama (KUA) setempat ${ }^{.47}$

Dalam regulasi undang-undang perkawinan disebutkan bahwa seorang perempuan yang masih berumur 16 tahun 1 hari harus mendapatkan izin orang tua jika ia ingin menikah, sementara jika ia baru berumur 15 tahun 29 hari, maka ia harus mendapatkan dispensasi dari pengadilan, tapi karena orang tunya tidak mau pusing maka dinikahkan dahulu sehingga dianggap nikah siri. Ada lagi penyebab yang lain nikah siri di Sulawei Barat, yaitu bahwa ada perempuan yang mengalami tabrakan kelamin, sehingga mengakibatkan tubuhnya penyot keluar (hamil duluan sebelum menikah), maka nikah siri dijadikan solusi jangka pendek untuk membungkus aibnya dan menjaga rasa malunya, karena tidak ingin diketahui oleh orang lain dan masyarakat, sehingga ia memanggil imam untuk menikahkannya secara siri dan pernikahan siri seperti ini tidak hanya terjadi di kalangan wanitia di bawah umur bahkan banyak terjadi dan dilakukan oleh wanita dewasa dan mereka tidak melaporkan atau mencatatkan pernikahannyakarena adanya perasaan malu telah hamil duluan sebelum menikah, tetapi ketika perempuan itu akan melahirkan dan diminta buku nikahnya di BPJS barulah pasangan ini melaporkan pernikahannya ke Kantor Urusan Agama (KUA) ${ }^{48}$

\section{Faktor Menghindari Perzinahan}

\footnotetext{
${ }^{46}$ H. Khalid Rasyid, Kepala Kantor Urusan Agama (KUA) Kecamatan Campalagiang. Wawancara; Polewali Mandar, 16 November 2017.HKR. Wawancara, 2017.

${ }^{47}$ HKR. Wawancara, 2017.

${ }^{48}$ HKR. Wawancara, 2017.
} 
Menurut salah seorang responden wanita yang tidak mau disebutkan namanya bahwa salah satu sebab terjadinya nikah siri hanya untuk menghindari perzinahan. Apalagi jika salah satu pasangan mengidap penyakit kronis yang mengurangi bahkan menurunkan kesehatan dan kenormalan alat refroduksi, di mana pihak istri atau suami tidak lagi dapat melayani kebutuhan biologis salah satu pihak, sementara hasrat seksual dan libido pihak lain tidak lagi terbendung yang jika tidak disalurkan akan menjadi sumber penyakit bagi suami atau istri yang dapat menyebabkan sakit kepala dan menyebabkan munculnya penyakit prostat pada saluran kencingya. Hal ini disebabkan oleh karena Sperma itu sifatnya panas. Itulah sebabnya laki-laki yang kuat libidonya didorong untuk melakukan poligami agar libidonya bisa tersalurkan dan tidak menjadi sumber penyakit baginya, seorang suami yang tidak mendapakan pelayanan seksual dari istrinya cenderung untuk marah-marah karena menyebabkan sakit kepala tetapi seorang suami yang menyalurkan libidonya secara teratur cenderung berkata dan bersikap baik kepada istrinya karena beban libido yang ada di kepalanya telah tersalurkan dengan baik dan dilepaskan sehingga menyehatkan organ-organ syarafnya.

Karena itu, dalam pandangan responden yang tidak ingin disebutkan namanya tersebut di atas, bahwa faktor kurangnya perhatian dan pelayanan seks salah satu pihak menjadi penyebab utama terjadinya perselingkuhan dan perzinahan dalam masyarakat. Ia menambahkan bahwa penyebab perzinahan dalam masyarakat disebabkan oleh karena pasangan muda mudi atau dua sejoli yang dimabuk cinta yang tidak bisa lagi dipisahkan karena saling mencintai namun perkawinannya ditentang oleh salah satu orang tua dari pasangan muda mudi tersebut, maka jalan keluar yang ditempu adalah perzinahan dan setelah hamil mereka melakukan nikah siri. Kedua pasangan itu bukannya tidak menyadari pentingnya perkawinan tercatat atau pentingnya buku nikah namun karena ibu dari laki-laki tersebut terus berupaya memisahkan keduanya, maka laki-laki tersbut nekad untuk melakukan nikah siri, baginya urusan pencatatan pernikahan dan adanya buku nikah dapat diurus setelah keduanya menikah.

\section{PENUTUP}

Berdasarkan paparan di atas, maka dapat disimpulkan bahwa faktor-faktor terjadinya nikah siri di Sulawesi Barat di kalangan laki-laki adalah Di antara sebabsebab terjadinya nikah siri di Sulawesi Barat antara lain adalah karena menganggap buku nikah tidak penting, kurangnya sosialisasi pentingnya pernikahan yang tercatat, memang ingin menikah $2 \mathrm{kali} /$ poligami, suami melakukan pernikahan tanpa izin istrinya, kurangnya perhatian dan pelayanan seks dan menghindari perzinahan. Sementara di kalangan perempuan, alasan mereka melakukan nikah siri antara lain adalah karena kebutuhan batin, tidak mendapatkan kepuasan dari suaminya, mencari laki-laki yang mapan dalam bidang ekonomi, sehingga dapat membiayai hidupnya, adanya jumlah perepuan yang terlalu banyak dibanding laki-laki.

\section{DAFTARA PUSTAKA}

Adhim, Muhammad Fauzil, Indahnya Pernikahan Dini Jakarta; Gema Insani Press, 2002 .

Ali, Atabik, Kamus Kontemporer Indonesia Arab. terj. Dari judul asli “Kamus al-Ashri Arabi Indonesia, tt: tp:, t.th. 
Anshary, M. MK, Hukum Perkawinan di Indonesia; Masalah-Masalah Krusial, Cet. I; Yogyakarta: Pustaka Pelajar, 2010.

Departemen Agama, Alquran dan Tarjamahnya Jakarta: Yayasan Penyelenggara Penterjemahan/Penafsir Alquran, 1971.

Departemen Pendidikan Nasional RI, Kamus Besar Bahasa Indonesia, Bandung: PT. Gramedia Pustaka Utama, 2002.

Djubaidah, Neng, Pencatatan Perkawinan dan Perkawinan Tidak Dicatat Menurut Hukum Tertulis di Indonesia dan Hukum Islam.

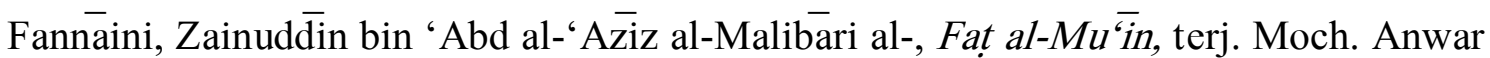
dkk, Terjemahan Fathul Mu'in, Juz II Cet. VII; Bandung: Sinar Baru Algensindo, 2014.

Gazaly, Abd. Rahman, Fiqh Munakahat, Jakarta: Kencana, 2006.

Halawi, Muhammad 'Abdul 'Ā̄iz al-, Fatawa wa Aqdiyah Amīil Mukminīin 'Umar ibn al-Khattab, terj. Zubeir Suryadi Abdullah, Fatwa dan Ijtihad Umar bin Khattab; Ensiklopedia Berbagai Persoalan Fiqih, Cet. I; Surabaya: Risalah Gusti, 1999.

Hazairin, Hukum Kekeluargaan Nasional Indonesia, Jakarta: Timtanas, 1961.

Ibn Manzūr, Abu al-Fadl Muhammad, Lisān al- 'Arab, Jilid. 6, t.t.: Dār al-Ma’arif, t.th..

Jamil, Muhammad Jamal, Korelasi Hukum Undang-Undang No. 1 Tahun 1974 tentang Pernikahan dan Inpres No. 1 Tahun 1991 tentang Kompilasi Hukum Islam Makassar: Alauddin University Press, 2011.

Jaziri, A $\underline{b} d u r r a h m a n$ al-, al-Fiqh ala al-Mazāhib al-Arba'ah, Jilid. 4, Beirü-Libanon: Dar al-Fikr, 1989

Muammar, Ahsin, Nikah Bahwah Tangan Versi Anak Kampus Jakarta: Qultum Media, 2005.

Nasution, Khairuddin, Status Wanita di Asia Tenggara: Studi Terhadap Perundangundangan Pernikahan Muslim Kontemporer di Indonesia dan Malaysia, JakartaLeiden: INIS, 2002.

Nuh, Abddullah bin dan Umar Bakri, Kamus Arab Indonesia Inggris, Jakarta, Penerbit Mutiara, MCMLXXIV.

Nur, Djaman, Fikih Munakahat, Cet. I; Semarang: Toha Putra, 1993.

Prawirohamidjojo, R. Soetojo, Pluralisme Dalam Perundang-undangan Pernikahan di Indonesia, Surabaya: Airlangga University Press, 1994.

Ramulyo, Idris, Hukum Pernikahan Islam, Suatu Analisis dari UU No. 1 yang 1974 dan Kompilasi Hukum Islam (Jakarta: Bumi Akasara, 2004.

Rasyidi, Lili, Hukum Pernikahan dan Perceraian di Malaysia dan Indonesia, Cet. I; Bandung: Remaja Rosdakarya, 1991.

Republik Indonesia, Undang-Undang Nomor 23 Tahun 2006 tentang Administrasi Kependudukan, Pasal 8.

Sahar, Saidus, Undang-undang Pernikahan dan Masalah Pelaksanan Ditinjau dari Hukum Islam, Bandung: Alumni, 2009.

Shihab, M. Quraish, Perempuan, Jakarta: Lentera hati, 2005.

Yusuf, Mahmud, Hukum Pernikahan dalam Islam, Jakarta: Hadakarya Agung.

Zuhāili, Wahbah al-, al-Fiqh al-Islam wa Adillatuhu, Jilid 7, Beirut: Där al- Fikr, 1991. 


\section{Sumber Wawancara}

Abdul Haris Nawami, Kepala Kantor Urusan Agama (KUA) Kecamatan Binuang. Wawancara; Polewali Mandar, 24 Desember 2017.

Bukhari. Tokoh Agama/ Pengulu Polewali Mandar. Wawancara; 15 Desember 2017.

H. Khalid Rasyid, Kepala Kantor Urusan Agama (KUA) Kecamatan Campalagiang. Wawancara; Polewali Mandar, 16 November 2017.HKR. Wawancara, 2017.

Kasman Hamal, Kepala Kantor Urusan Agama (KUA) Kecamatan Mamuju. Wawancara; Mamuju, 29 November 2017

M. Sahid, Kepala Kantor Urusan Agama (KUA) Banggae. Wawancara, Majene, 20 Oktober 2017.

Sabir, Kepala Kantor Urusan Agama (KUA) Tappalang Barat. Wawancara; Mamuju, 17 November 2017.

Syamsuddin, Anggota DPR Kabupaten Mamuju, Pelaku Nikah Siri. Wawancara; Mamuju, 17 November 2017. 